of: AbbVie, N. Matsuda Shareholder of: AbbVie, Employee of: AbbVie, S. Meerwein Shareholder of: AbbVie, Employee of: AbbVie, H. Kameda Grant/research support from: AbbVie GK, Astellas Pharma Inc, Bristol-Myers Squibb Company, Chugai Pharmaceutical Co Ltd, Mitsubishi-Tanabe Pharma Corporation and Novartis Pharma KK., Speakers bureau: AbbVie GK, Bristol-Myers Squibb Company, Chugai Pharmaceutical Co Ltd, Eli Lilly Japan KK, Janssen Pharmaceutical KK, Mitsubishi-Tanabe Pharma Corporation, Novartis Pharma KK and Sanofi KK DOI: 10.1136/annrheumdis-2018-eular.4302

\section{SAT0258 WEEKLY SPLIT DOSE COMPARED WITH SINGLE DOSE ORAL METHOTREXATE REDUCED POLYGLUTAMYLATION IN RED BLOOD CELLS AND INCREASED THE RISK OF ADVERSE EVENTS IN PATIENTS WITH RHEUMATOID ARTHRITIS}

Y. Yoshioka ${ }^{1}$, K. Katayama ${ }^{2}$, T. Kasama ${ }^{3}$, M. Sato ${ }^{4}$, S. Ohno ${ }^{5}$, Y. Amasaki ${ }^{6}$, H. Kataoka ${ }^{7}$, D. Kanai ${ }^{1}$, A. Suda ${ }^{1}$, M. Okamoto ${ }^{8}$, M. Sasano ${ }^{8}$, S. Nagaoka ${ }^{1}$, A. Sagawa ${ }^{9}$ on behalf of ADDMe trial Group. ${ }^{1}$ Yokohama Minami Kyosai Hospital, Yokohama; ${ }^{2}$ Katayama Orthopedic Rheumatology Clinic, Asahikawa; ${ }^{3}$ Showa University Koto-Toyosu Hospital, Tokyo; ${ }^{4}$ Ohashi Tani Orthopedic Hospital, Gifu; ${ }^{5}$ Yokohama City University Medical Center, Yokohama; ${ }^{6}$ KKR Sapporo Medical Center, ${ }^{7}$ Sapporo City General Hospital, Sapporo; ${ }^{8}$ AYUMI pharmaceutical. Corporation, Kyoto; ${ }^{9}$ Sagawa Akira Rheumatology Clinic, Sapporo, Japan

Background: Methotrexate (MTX) is a well-known anchor drug for rheumatoid arthritis (RA); however, dose regimens vary. We previously reported in EULAR2015 that split dose weekly oral methotrexate induced elevation of AST and ALT in association with elevation of MTX with 2 glutamates (MTX-PG2) in a single-centre trial.

Objectives: We performed a multi-centre randomised controlled trial to compare the incidence of adverse events using single and split dose regimens.

Methods: Six hospitals and 2 rheumatology clinics participated in this study. Seventy-eight patients with insufficient control on MTX $8 \mathrm{mg} /$ week were randomly assigned to 2 groups, i.e., a single weekly dose regimen with 39 patients and a 3 dose per week regimen with 39 patients. The MTX dose in all patients was gradually increased to $16 \mathrm{mg} /$ week. The primary endpoint was the occurrence of liver dysfunction during the observation period ( 20 weeks). Other endpoints included the incidence of adverse events and the changes from baseline in the disease activity score (DAS28) based on ESR or CRP, the Simplified Disease Activity Index (SDAI), and MTX-PG at week 20.

Results: There were no differences between the groups in baseline data and MTX dose at 20 weeks (single dose: $10.2 \pm 0.8$ vs. 3 -dose: $10.2 \pm 0.9 \mathrm{mg} /$ week). Liver dysfunction occurred in 3 patients $(7.7 \%)$ receiving the single dose regimen and in 5 patients $(13.2 \%)$ receiving the 3 -dose regimen, but there was no significant difference in the incidence in both groups $(p=0.455)$. There was a significant difference in the incidence of adverse events (gastrointestinal disorder was most common) between single dose (11 patients, 28.9\%) and 3-dose (20 patients, $52.6 \%)$ regimens $(p=0.036)$. There was no significant difference in the changes from baseline in DAS28-ESR (-1.55 vs. -1.36$)$, DAS28-CRP (-1.31 vs. -1.26$)$, or SDAI ( -9.45 vs. -10.11$)$. Compared to the single dose regimen, MTX-PG2 was significantly increased in the 3-dose regimen, and MTX-PG3, -PG4, and PG5 were significantly increased in the single dose regimen (table 1).

Abstract SAT0258 - Table 1. MTX-PG changes from baseline in red blood cells at week 20.

\begin{tabular}{lcccc}
\hline & $\begin{array}{c}\text { Single dose } \\
\text { Mean } \\
(\mathrm{n}=28) \\
(\mathrm{nmol} / \mathrm{L})(1)\end{array}$ & $\begin{array}{c}\text { 3-dose } \\
\text { Mean } \\
(\mathrm{n}=27) \\
(\mathrm{nmol} / \mathrm{L})(2)\end{array}$ & $\begin{array}{c}\text { Difference } \\
((2)-(1)) \\
\text { Mean }(95 \% \mathrm{Cl})\end{array}$ & $\begin{array}{c}\mathrm{P} \\
\text { (Wilcoxon) }\end{array}$ \\
\hline MTX- & 22.95 & 57.9 & $\begin{array}{c}34.95(-56.99, \\
126.89)\end{array}$ & 0.448 \\
PG1 & -1.14 & 17.36 & $18.50(12.73-24.27)$ & $<0.001$ \\
MTX- & 39.24 & 27.83 & $-11.41(-21.51,-$ & 0.032 \\
PG2 & & & $1.32)$ & $<0.001$ \\
MTX- & 15.43 & 5.10 & $-10.33(-15.03,-$ & \\
PG3 & & & $5.63)$ & $<0.001$ \\
MTX- & 3.36 & 0.15 & $-3.22(-4.73,1.69)$ & \\
PG4 & & & &
\end{tabular}

Conclusions: There were no differences in the incidence of liver dysfunction and efficacy according to the oral MTX dose regimen; however, split weekly dosing compared with single weekly dosing reduced polyglutamylation and increased the risk of adverse events.

Acknowledgements: Clinical registration: UMIN000021157

Disclosure of Interest: Y. Yoshioka: None declared, K. Katayama: None declared, T. Kasama: None declared, M. Sato: None declared, S. Ohno: None declared, Y. Amasaki: None declared, H. Kataoka: None declared, D. Kanai: None declared, A. Suda: None declared, M. Okamoto Employee of: AYUMI Pharmaceutical Corporation, M. Sasano: None declared, S. Nagaoka: None declared A. Sagawa: None declared DOI: 10.1136/annrheumdis-2018-eular.5046

\section{SATURDAY, 16 JUNE 2018 \\ Spondyloarthritis - treatment}

\section{SAT0259 LOW RATE OF SPINAL RADIOGRAPHIC PROGRESSION OVER 2 YEARS IN ANKYLOSING SPONDYLITIS PATIENTS TREATED WITH SECUKINUMAB: A HISTORICAL COHORT COMPARISON}

J. Braun $^{1}$, H. Haibel ${ }^{2}$, M. de Hooge ${ }^{3,4}$, R. Landewé ${ }^{5}$, M. Rudwaleit ${ }^{6}$, T. Fox ${ }^{7}$, A. Readie ${ }^{8}$, H.B. Richards ${ }^{7}$, B. Porter ${ }^{8}$, R. Martin ${ }^{8}$, D. Poddubny' ${ }^{2}$, J. Sieper ${ }^{2}$, D. van der Heijde ${ }^{3} .{ }^{1}$ Rheumazentrum Ruhrgebiet, Herne; ${ }^{2}$ Charité Universitätsmedizin Berlin, Berlin, Germany; ${ }^{3}$ Leiden University Medical Centre, Leiden, Netherlands; ${ }^{4}$ VIB Inflammation Research Center, Ghent, Belgium; ${ }^{5}$ Maastricht University Medical Center, Maastricht, Netherlands; ${ }^{6}$ Klinikum Bielefeld, Bielefeld, Germany; ${ }^{7}$ Novartis Pharma AG, Basel, Switzerland; ${ }^{8}$ Novartis Pharmaceuticals Corporation, East Hanover, USA

Background: Secukinumab, a fully human interleukin 17A (IL-17A) inhibitor improved signs and symptoms of ankylosing spondylitis (AS) in patients (pts) in the MEASURE 1 core trial at 2 years and through 4 years in the extension study. ${ }^{1,2}$ A low radiographic progression rate was reported for the modified Stoke Ankylosing Spondylitis Spinal Score ( $\Delta$ mSASSS at $\mathrm{Yr} 2=0.3) .{ }^{1}$ Comparison of anti-TNF agents with historical NSAID-treated cohorts have not shown a significant benefit at 2 years in reducing radiographic progression. ${ }^{3,4}$

Objectives: This retrospective analysis compared spinal radiographic progression over 2 years in the MEASURE 1 cohort of secukinumab-treated AS patients (C1; NCT01358175) vs a historical cohort of biologic-naïve AS pts (ENRADAS [C2; NCT00715091])..$^{5}$

Methods: Baseline $(\mathrm{BL})$ and 2 year $\mathrm{X}$-ray data from the 2 cohorts were com pared. Only data from pts with X-rays at $B L$ and $\mathrm{Yr} 2$ (data capture window for $\mathrm{Yr} 2$ X-rays: $31-744$ days) were included ( $n=168$ [C1], $n=69$ [C2]). X-rays were independently re-evaluated using the mSASSS by 2 reviewers and an adjudicator blinded to the timing and cohorts; averaged values were analysed. Cases with the highest difference in $\triangle$ mSASSS between readers (top 10\%) were adjudicated. The primary outcome was to compare the $\%$ pts with no radiographic progression ( $\Delta$ mSASSS at Year $2 \leq 0$ ) in C1 vs C2. The difference between $\mathrm{C} 1$ and $\mathrm{C} 2$ was analysed using a logistic regression with cohort as a factor and BL mSASSS as a covariate.

Results: BL demographics were comparable across cohorts, with mean age 40.9 vs 42.6 years, and gender $72.8 \%$ vs $66.7 \%$ male in C1 vs C2, respectively. Over 2 years, least squares (LS) mean $\Delta$ mSASSS was 0.55 for C1 vs 0.89 for C2 $(\mathrm{p}=0.185)$ and $\%$ pts with no radiographic progression $(\Delta$ mSASSS at Year $2 \leq 0)$ was slightly higher in C1 vs C2 (table 1).

Abstract SAT0259 - Table 1. Radiographic status at Yr 2

\begin{tabular}{|c|c|c|c|}
\hline & $\begin{array}{c}\text { C1 } \\
\text { (MEASURE } \\
1 \text { ) } \\
n=168\end{array}$ & $\begin{array}{c}\text { C2 } \\
\text { (ENRADAS) } \\
n=69\end{array}$ & $\begin{array}{l}\text { Odds ratio/difference of LS } \\
\text { mean }(95 \% \mathrm{Cl}), p \text {-value }\end{array}$ \\
\hline BL mSASSS (SD) & $9.55(14.14)$ & $9.95(13.76)$ & \\
\hline mSASSS at $\mathrm{Yr} 2$ (SD) & $\begin{array}{c}10.10 \\
(14.70)\end{array}$ & $\begin{array}{c}10.85 \\
(14.66)\end{array}$ & \\
\hline $\begin{array}{l}\triangle \text { mSASSS over } 2 \text { years, } \\
\text { LS mean (SE) }\end{array}$ & $0.55(0.14)$ & $0.89(0.22)$ & $p=0.185$ \\
\hline $\begin{array}{l}\text { No progression ( } \Delta \\
\text { mSASSS } \leq 0), \%\end{array}$ & $61 \%$ & $52 \%$ & $1.43(0.79,2.60), p=0.243$ \\
\hline $\begin{array}{l}\text { No progression }(\Delta \\
\text { mSASSS }<2), \%\end{array}$ & $82 \%$ & $73 \%$ & $1.84(0.90 ; 3.77), p=0.093$ \\
\hline
\end{tabular}

$\mathrm{Cl}$, confidence interval; SD, standard deviation; SE, standard error 


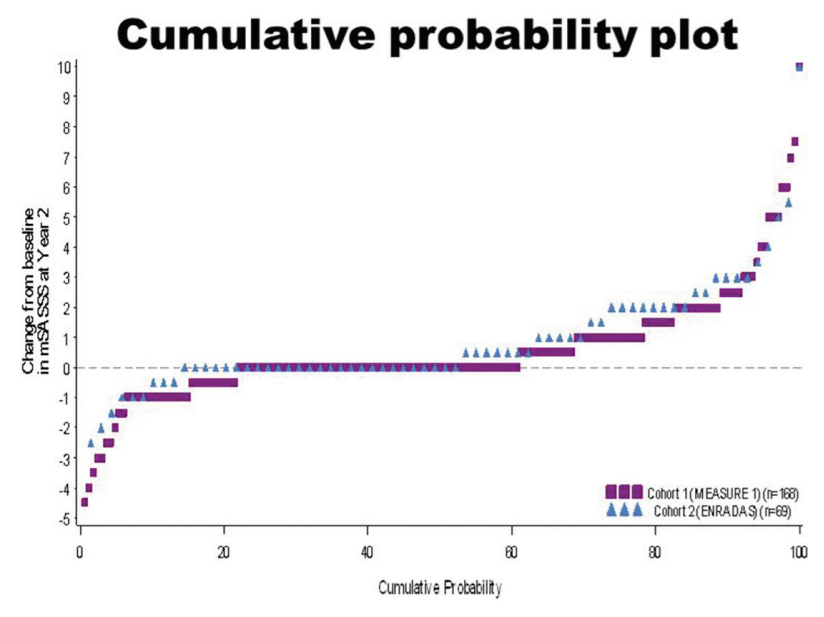

Conclusions: Over 2 years, a numerically lower rate of progression was seen in secukinumab-treated pts vs a control cohort of biologic-naïve AS pts. Further research is needed to understand the impact of IL-17A inhibition with secukinumab on spinal disease progression in AS pts; SURPASS (NCT03259074), an ongoing $\mathrm{H} 2 \mathrm{H}$ study powered to compare differences in spinal radiographic progression with secukinumab vs biosimilar adalimumab, will help answer these questions.

\section{REFERENCES:}

[1] Braun J, et al. Ann Rheum Dis Ann Rheum Dis 2017;76:1070-77.

[2] Braun J, et al. Arthritis Rheumatol 2017;69(10).

[3] van der Heijde D, et al. Arthritis Rheum 2008;58:1324-31.

[4] van der Heijde D, et al. Arthritis Res Ther 2009;11:R127.

[5] Sieper J, et al. Ann Rheum Dis 2016;75:1438-43.

Disclosure of Interest: J. Braun Grant/research support from: Abbvie (Abbott), Amgen, BMS, Boehringer, Celgene, Celltrion, Centocor, Chugai, EBEWE Pharma, Medac, MSD (Schering-Plough), Mundipharma, Novartis, Pfizer (Wyeth), Roche, Sanofi-Aventis and UCB, Consultant for: Abbvie (Abbott), Amgen, BMS, Boehringer, Celgene, Celltrion, Centocor, Chugai, EBEWE Pharma, Medac, MSD (Schering-Plough), Mundipharma, Novartis, Pfizer (Wyeth), Roche, Sanofi-Aventis and UCB, Speakers bureau: Abbvie (Abbott), Amgen, BMS, Boehringer, Celgene, Celltrion, Centocor, Chugai, EBEWE Pharma, Medac, MSD (Schering-Plough), Mundipharma, Novartis, Pfizer (Wyeth), Roche, Sanofi- Aventis and UCB, H. Haibel: None declared, M. de Hooge Employee of: MdH Research, R. Landewé Grant/research support from: Abbott, Amgen, Centocor, Novartis, Pfizer, Roche, Schering-Plough, UCB and Wyeth, Consultant for: Abbott/AbbVie, Ablynx, Amgen, Astra-Zeneca, BristolMyers Squibb, Centocor, GlaxoSmithKline, Novartis, Merck, Pfizer, Roche, Schering-Plough, UCB and Wyeth, Employee of: Rheumatology Consultancy BV, Speakers bureau: Abbott, Amgen, Bristol-Myers Squibb, Centocor, Merck, Pfizer, Roche, Schering-Plough, UCB and Wyeth, M. Rudwaleit Speakers bureau: Abbvie, BMS, Celgene, Chugai, Janssen, MSD, Novartis, Pfizer, UCB, T. Fox Shareholder of: Novartis, Employee of: Novartis Pharma AG, A. Readie Shareholder of: Novartis, Employee of: Novartis Pharmaceuticals Corporation, H. Richards Shareholder of: Novartis, Employee of: Novartis Pharma AG, B. Porter Shareholder of: Novartis, Employee of: Novartis Pharmaceuticals Corporation, R. Martin Shareholder of: Novartis, Employee of: Novartis Pharmaceuticals Corporation, D. Poddubny Grant/research support from: Abbvie, Janssen, MSD, Novartis and Pfizer, Consultant for: AbbVie, Bristol-Myers Squibb, MSD, Novartis, Pfizer and UCB, Speakers bureau: AbbVie, Bristol-Myers Squibb, Janssen, MSD, Novartis, Pfizer, Roche and UCB, J. Sieper Grant/research support from: AbbVie, Boehringer Ingelheim, Janssen, Novartis, Merck, Lilly, Pfizer, and UCB, Consultant for: AbbVie, Janssen, Novartis, Merck, Lilly, Pfizer, Sun and UCB, Speakers bureau: AbbVie, Janssen, Novartis, Merck, Pfizer, Roche and UCB, D. van der Heijde Consultant for: AbbVie, Amgen, Astellas, AstraZeneca, BMS, Boeringer Ingelheim, Celgene, Daiichi, Eli-Lilly, Galapagos, Gilead, Janssen, Merck, Novartis, Pfizer, Regeneron, Roche, Sanofi and UCB, Employee of: Imaging Rheumatology BV

DOI: 10.1136/annrheumdis-2018-eular.1899

\section{SAT0260 \\ ELIGIBILITY CRITERIA FOR TNFI THERAPY IN AXSPA:} GOING BEYOND BASDAI

J.A. Marona ${ }^{1,2}$, A. Sepriano $0^{2,3}$, S. Rodrigues-Manica ${ }^{1,2}$, F. Pimentel-Santos ${ }^{1,2}$, A. F. Mourão $0^{1,2}$, N. Gouveia ${ }^{2}$, J.C. Branco ${ }^{1,2}$, F. Vinagre ${ }^{4}$, R. Roque ${ }^{4}$, J. Rovisco ${ }^{5}$, M. L. Marques ${ }^{5}$, J. Tavares-Costa ${ }^{6}$, J. Silva ${ }^{6}$, H. Santos ${ }^{7}$, N. Madeira ${ }^{7}$, E. VieiraSousa $^{8,9}$, R. Machado ${ }^{8}$, M. Bernardes ${ }^{10}$, R. Ferreira ${ }^{10}$, S. Ramiro ${ }^{2,3} \cdot{ }^{1} \mathrm{CHLO}$;

${ }^{2}$ CEDOC, NMS, Lisbon, Portugal; ${ }^{3}$ LUMC, Leiden, Netherlands; ${ }^{4} \mathrm{HGO}$, Almada; ${ }^{5} \mathrm{CHUC}$, Coimbra; ${ }^{6}$ ULSAM, Ponte de Lima; ${ }^{7}$ IPR; ${ }^{8} \mathrm{CHLN} ;{ }^{9} \mathrm{IMM}$, FMUL, Lisbon;

${ }^{10} \mathrm{CHSJ}$, Porto, Portugal

Background: A BASDAI $\geq 4$ has been often required to start TNFi therapy in patients with axSpA. However, this cut-off of high disease activity (HDA) is largely arbitrary. Unlike BASDAI, ASDAS incorporates objective measures (e.g. CRP) and has a validated definition of HDA $(\geq 2.1)$. It has thus been suggested that ASDAS could also be used to guide treatment decisions, but evidence to support this is still scarce.

Objectives: To compare the impact of applying the ASDAS and BASDAI definitions of HDA in selecting patients for TNFi-treatment in daily clinical practice Methods: Patients from Reuma.pt (Rheumatic Diseases Portuguese Register), with diagnosis of axSpA according to their rheumatologists (both treated and not treated with their first TNFi), with complete baseline BASDAI and ASDAS data, and complete 6 month of follow-up (i.e. baseline, 3 and 6 months visits available) were included. Four subgroups [cross-tabulation between ASDAS $(\geq 2.1)$ and BASDAI ( $\geq 4$ ) definitions of HDA], were compared according to baseline demographic and clinical characteristics in the 'eligible population' (i.e. irrespective of TNFi-treatment). In addition, for patients starting TNFi and with complete followup BASDAI/ASDAS data ('efficacy population'), the subgroups were also compared according to different response criteria (see table 1), at 3 and 6 months. Results: In total, 466 patients were included (59\% males and 66\% HLA-B27 positive). The large majority ( $n=382 ; 82 \%$ ) fulfilled the definition of HDA according to both BASDAl and ASDAS at baseline (i.e. BASDAI $\geq 4$ and ASDAS $\geq 2.1$ ). The frequency of $A S D A S \geq 2.1$, if BASDAl $<4$, was much higher than the opposite condition (i.e. ASDAS $<2.1$, if $\mathrm{BASDAl} \geq 4)(70 \%$ vs $0.5 \%)$. Compared to patients fulfilling both definitions, those who were ASDAS $>2.1$ only, were more likely to be male $(82.5 \%$ vs $54 \%)$, HLA-B27 positive $(79 \%$ vs $54 \%)$, to show higher levels of CRP $(2.6 \pm 2.5$ vs $2.2 \pm 2.8 \mathrm{mg} / \mathrm{dL}$ ) and lower BASFI $(3.1 \pm 2.6$ vs $5.6 \pm 2.3)$. In the 'efficacy population' ( $n=296)$, better responses were observed among patients with ASDAS $\geq 2.1$ only, especially for the most 'stringent' outcomes [e.g. ASDAS inactive disease (ASDAS ID): $59 \%$ and $50 \%$, at 3 and 6 months respectively], compared to patients fulfilling both definitions (ASDAS ID: $26 \%$ and $25 \%$ at 3 and 6 months respectively) (table 1 ).

Abstract SAT0260 - Table 1. TNFi response criteria across subgroups according to BASDAI/ASDAS category ('efficacy population')

\begin{tabular}{|c|c|c|c|c|c|c|}
\hline \multirow[b]{2}{*}{ Variables } & \multirow[b]{2}{*}{$\begin{array}{c}\text { Overall } \\
(\mathrm{N}=296)^{*}\end{array}$} & \multicolumn{2}{|c|}{ ASDAS $\geq 2.1$} & \multicolumn{2}{|c|}{ ASDAS $<2.1$} & \multirow{2}{*}{$\begin{array}{c}\text { p-value } \\
* *\end{array}$} \\
\hline & & $\begin{array}{c}\text { BASDAI } \geq 4 \\
\text { (N=256) }\end{array}$ & $\begin{array}{c}\text { BASDAI <4 } \\
(\mathrm{N}=34)\end{array}$ & $\begin{array}{c}\text { BASDAI } \geq 4 \\
(\mathrm{~N}=1)\end{array}$ & $\begin{array}{c}\text { BASDAI <4 } \\
(\mathrm{N}=5)\end{array}$ & \\
\hline \multicolumn{7}{|c|}{ Outcomes - 3 months, n (\%) } \\
\hline ASAS20 & 159 (59) & $142(60)$ & 15 (56) & $a(0)$ & $2\langle 40\rangle$ & 0.48 \\
\hline ASAS40 & $127(47)$ & $111(46)$ & $14(52)$ & $a(0)$ & $2(40)$ & 0.74 \\
\hline ASAS PR & $73(26)$ & $56(22)$ & $14(56)$ & $a(0)$ & $3(60)$ & $<0.01$ \\
\hline BASDAI50 & $184(62)$ & $160(63)$ & $21(62)$ & $0(0)$ & $3(60)$ & 0.64 \\
\hline ASDAS CII & $207(70)$ & $179(70)$ & $26(77)$ & $a(0)$ & $2(40)$ & 0.16 \\
\hline ASDAS MI & $123(42)$ & $111(43)$ & $12(35)$ & $a(0)$ & $0(0)$ & 0.16 \\
\hline ASDAS ID & $90\langle 30\rangle$ & $66(26)$ & $20(59)$ & $a(0)$ & $4(80)$ & $<0.01$ \\
\hline \multicolumn{7}{|c|}{ Outcomes - 6 months, n (\%) } \\
\hline ASAS20 & $160(61)$ & $139(61)$ & $18(62)$ & $a(0)$ & $3\langle 60\rangle$ & 0.67 \\
\hline ASAS40 & $124(46)$ & $104(45)$ & $17(57)$ & $a(0)$ & $3\langle 60\rangle$ & 0.43 \\
\hline ASAS PR & $74(27)$ & $57(24)$ & $13(48)$ & $a(0)$ & $4(80)$ & $<0.01$ \\
\hline BASDAISO & $188(64)$ & $167(65)$ & $18(53)$ & $0(0)$ & $3(60)$ & 0.29 \\
\hline ASDAS CII & $216(73)$ & $190(74)$ & $25(74)$ & $a(0)$ & $1(20)$ & 0.02 \\
\hline ASDAS MI & $128(43)$ & $117(46)$ & 11 (32) & $a(0)$ & $0(0)$ & 0.08 \\
\hline ASDAS ID & $84\{28\}$ & $63(25)$ & $17(50)$ & $\alpha(0)$ & $4(80)$ & $<0.01$ \\
\hline
\end{tabular}

Conclusions: Our results show that the ASDAS-HDA definition (ASDAS $\geq 2.1$ ) is more inclusive than the BASDAI-HDA definition $(\geq 4)$ in selecting axSpA patients for TNFi treatment. Importantly, the additionally 'captured' patients respond better and have higher likelihood of predictors thereof. These results support the use of ASDAS $\geq 2.1$ as a selection criterion for treatment decisions.

Acknowledgements: Supported in part by a research Grant from InvestigatorInitiated Studies program of MSD

Disclosure of Interest: J. Marona Grant/research support from: MSD, A. Sepriano Grant/research support from: MSD, S. Rodrigues-Manica Grant/ research support from: MSD, F. Pimentel-Santos Grant/research support from: MSD, A. Mourão Grant/research support from: MSD, N. Gouveia Grant/research support from: MSD, J. Branco Grant/research support from: MSD, F. Vinagre 